\title{
Effects of antibiofilm compounds on the cellular and bacterial colonization of polimeric surfaces: a step towards biofunctionalization of implantable devices
}

\author{
Armando Rodrigues Lopes Pereira Neto ${ }^{1 *}$, Lya Piaia ${ }^{1}$, Camila Quinetti Paes ${ }^{1}$, Aguedo Aragones², \\ Ricardo de Souza Magini ${ }^{2}$, Luismar Marques Porto ${ }^{1}$, Ulisses Alves Pereira ${ }^{3}$, Luiz Claudio de Almeida Barbosa ${ }^{3}$, \\ Andrea de Lima Pimenta ${ }^{2}$
}

From 5th Congress of the Brazilian Biotechnology Society (SBBIOTEC)

Florianópolis, Brazil. 10-14 November 2013

\section{Background}

Periodontal and peri-implant diseases are infection pathologies related to the pathogenicity of the microorganisms involved [1]. The worldwide practice of indiscriminate and continuous use of antibiotics for the control and prophylaxis of bacterial pathogens has led to the development of bacterial resistance to most available antimicrobials [2]. Concurrently, the rapid increase in bacterial resistance to currently available antimicrobial drugs has led researchers to search for new sources of molecules active against bacterial pathogens, outlining a new generation of anti-infective drug development. A promising approach for the development of a new generation of antimicrobial drugs has arisen from the studies of host-pathogen interactions, which prompted a shift of drug targets from bacterial survival to pathogenicity control. Examples of potential nonconventional targets for microbial control are molecules and receptors involved in bacterial adherence to biotic and abiotic surfaces as well as signal systems controlling bacterial group behaviour of populations organised in biofilms, such as quorum sensing (QS) [3]. In contrast to conventional antibiotics, antimicrobial drugs directed against such unconventional targets do not jeopardise bacterial survival, imposing a low selection pressure and thus avoiding the development of resistance [4].

'Department of Chemical Engineering and Food Engineering, Federal University of Santa Catarina (UFSC), Integrated Technologies Laboratory Florianópolis, Santa Catarina, Brazil

Full list of author information is available at the end of the article

\section{Methods}

Here we analysed the effects of novel synthetic lactams, compounds derived from furanones which display recognized antibiofilm activity. Three synthetic lactams were tested against biofilm of Enterococcus faecalis grown over an implantable polymeric material (PLGA-HA). Inhibition assays of adhesion and biofilm formation, and SEM observation were used to quantify and qualify E. faecalis' biofilm formation. To assay for biofilm inhibition, bacterial strains were grown statically for $20 \mathrm{~h}$ at $37^{\circ} \mathrm{C}$ in TSB. Polystyrene 96-well microtitre plates were inoculated with $100 \mu \mathrm{L} /$ well of bacterial suspension previously diluted to $5 \times 10^{8} \mathrm{CFU} / \mathrm{mL}$ in TSB supplemented with $4 \%$ sucrose $(\mathrm{w} / \mathrm{v})$ and $3.5 \%(\mathrm{v} / \mathrm{v})$ dimethyl sulphoxide (DMSO). Compounds to be tested for antibiofilm activity were prepared at a concentration of $175 \mu \mathrm{g} / \mathrm{ml}$, in the same media as before, and added to the test wells. Biofilm inhibition capacity was assessed by CFU counting after bacterial disaggregation from the surfaces and microscopic analysis of the polymers. Cytotoxicity of the lactams against human fibroblasts and keratinocytes was tested, at four different concentrations $(43,75 ; 87,5$; $131,25$ and $175 \mu \mathrm{g} / \mathrm{ml})$, by MTT assay [5].

\section{Results and conclusions}

All compounds showed biofilm inhibition rates higher than $99 \%$, as accessed by CFU counting and in agreement with images obtained by SEM. At the MIC (minimum inhibitory concentration) human cells viability indexes of all compounds were higher than those recommended for 
approval in clinical use. Results presented here indicate that lactams have excellent potential for use in the treatment of periodontal disease and in association with PLGA-HA can be used in the prevention of peri-implantitis disease.

\section{Authors' details}

'Department of Chemical Engineering and Food Engineering, Federal University of Santa Catarina (UFSC), Integrated Technologies Laboratory Florianópolis, Santa Catarina, Brazil. '2Department of Odontology, Federal University of Santa Catarina (UFSC), Dental Implants Teaching and Research Center - Florianópolis, Santa Catarina, Brazil. ${ }^{3}$ Department of Chemistry, Federal University of Viçosa - Viçosa, Minas Gerais, Brazil.

Published: 1 October 2014

\section{References}

1. Socransky SS, Haffajee AD: The bacterial etiology of destructive periodontal disease: current concepts. J Periodontol 1992, 63(Suppl 3):322-331.

2. Richards JJ, Melander C: Controlling bacterial biofilms. Chembiochem 2009, 10:2287-2294.

3. Chen $G$, Swem $L R$, Swem DL, Stauff DL, O'Loughlin $C T$, Jeffrey $P D$, Bassler BL, Hughson FM: A strategy for antagonizing quorum sensing. Mol Cell 2011, 42:199-209.

4. Kolter R: Biofilms in lab and nature: a molecular geneticist's voyage to microbialecology. Int Microbiol 2010, 13:1-7.

5. Sieuwerts AM, Klijn JG, Peters HA, Foekens JA: The MTT tetrazolium salt assay scrutinized: how to use this assay reliably to measure metabolic activity of cell cultures in vitro for the assessment of growth characteristics, IC50-values and cell survival. Eur I Clin Chem Clin Biochem 1995, 33:813-823.

doi:10.1186/1753-6561-8-S4-P71

Cite this article as: Pereira Neto et al:: Effects of antibiofilm compounds on the cellular and bacterial colonization of polimeric surfaces: a step towards biofunctionalization of implantable devices. BMC Proceedings 2014 8(Suppl 4):P71.

\section{Submit your next manuscript to BioMed Central and take full advantage of:}

- Convenient online submission

- Thorough peer review

- No space constraints or color figure charges

- Immediate publication on acceptance

- Inclusion in PubMed, CAS, Scopus and Google Scholar

- Research which is freely available for redistribution

Submit your manuscript at www.biomedcentral.com/submit
C Biomed Central 